\title{
Safety and efficacy of interleukin inhibitors in elderly patients with rheumatoid arthritis, psoriasis, and psoriatic arthritis
}

\author{
Jasmina Djuretić $^{1^{*}}$ and Biljana Bufan ${ }^{2}$
}

\author{
1 University of Belgrade - Faculty of Pharmacy, Department of Pathobiology, \\ Vojvode Stepe 450, 11221 Belgrade, Serbia \\ ${ }^{2}$ University of Belgrade - Faculty of Pharmacy, Department of Microbiology and \\ Immunology, Vojvode Stepe 450, 11221 Belgrade, Serbia
}

*Corresponding author: Jasmina Djuretić, e-mail: jasmina@pharmacy.bg.ac.rs

\begin{abstract}
Elderly patients with rheumatoid arthritis, psoriasis and psoriatic arthritis encompass those with elderly-onset disease, over 60 years of age, but also those with earlier disease onset who entered old age. Considering the age-related changes of the immune system, possible frailty, susceptibility to infection and concomitant comorbidity that implies multiple medicines, the treatment of these diseases in elderly patients can be challenging. Interleukin inhibitors have been shown to be an efficient and safe treatment for these diseases. However, elderly patients with these diseases were often included in the pivotal clinical trials for interleukin inhibitors in numbers insufficient to determine whether they responded differently from younger subjects. The aim of this paper was to review the findings on the efficacy and safety of interleukin inhibitor treatment in elderly patients with rheumatoid arthritis, psoriasis, and psoriatic arthritis. The findings suggest that, for all the interleukin inhibitors reviewed herein, used in elderly patients with rheumatoid arthritis, or with psoriasis and psoriatic arthritis, the efficacy was comparable to younger patients. Furthermore, the incidence of reported adverse events was similar in these two age groups. Severe adverse events, which were related to sarilumab treatment for rheumatoid arthritis and secukinumab treatment for psoriasis, were higher in elderly patients. The reviewed findings suggest that the interleukin inhibitors approved and currently in use in clinical practice for the treatment of rheumatoid arthritis, psoriasis, and psoriatic arthritis can be considered a safe and efficient option for these diseases in elderly patients.
\end{abstract}

Key words: interleukin inhibitors, elderly patients, safety, efficacy

doi.org/10.5937/arhfarm71-30505 


\section{Introduction}

Prolonged human life expectancy and global decline in fertility rates have led to an increase in the age of the population in almost all regions of the world (1). The United Nations demographic projections from 2019 indicate that the number of people over the age of 65 will have doubled by 2050 (1). Along with the extension of the human lifespan, the need for the society to provide adequate care for the elderly with health problems is growing.

Rheumatoid arthritis and psoriasis are among the most prevalent chronic inflammatory diseases (2-4). An inflammatory process in rheumatoid arthritis primarily affects the joints $(2,5)$. A multisystem inflammation present in psoriasis predominantly affects the skin and joints $(6,7)$. Psoriatic arthritis is present in $6-42 \%$ of patients with psoriasis $(3,8-11)$.

Elderly patients with rheumatoid arthritis may be those with a late-onset rheumatoid arthritis and those in whom the disease started at an earlier age and lasted until old age. The prevalence of rheumatoid arthritis in elderly population ( $\geq 60$ years) is approximately $2 \%$ (12). Late- or elderly-onset rheumatoid arthritis refers to the disease onset at age 60 or over and represents 10-33\% of all cases of rheumatoid arthritis (13). A comparison of disease treatment in patients with elderly-onset and younger-onset rheumatoid arthritis, using the Consortium of Rheumatology Researchers of North America registry, revealed that patients with elderly-onset receive biological agents considerably less frequently than those with younger-onset rheumatoid arthritis, although no difference between disease duration, activity and severity was detected (14). Other studies also suggest that, even though elderly patients with rheumatoid arthritis have similar or greater disease activity compared to that present in younger patients, they do not receive the same treatment as younger patients with rheumatoid arthritis (15-20). It should be noted that, in addition to the observed clinical and laboratory differences between elderly-onset and younger-onset rheumatoid arthritis $(15,16,21)$, higher synovial fluid levels of interleukin (IL)-6 were detected in patients with elderly-onset rheumatoid arthritis than in those with younger onset (21). The use of multiple drugs seems to be more common and considerable among elderly patients with rheumatoid arthritis and patients with longer disease duration, most likely due to the developed comorbidities (22). Furthermore, it has been shown that age represents an important influencing factor for rheumatologists' decision to escalate care, such as the introduction of a new biological drug into therapy, in patients with rheumatoid arthritis (23).

One-quarter of psoriasis patients are those with late-onset psoriasis, that is, with the onset of the disease at or after the age of 40, with a peak between 57 and 60 years of age. $(24,25)$. A difference in genetic background has been reported among psoriasis patients with early- and late-onset psoriasis $(25,26)$. It has been suggested that polymorphism at the IL-1B gene is significantly associated with late-onset, but not early-onset psoriasis (27). Furthermore, studies of psoriasis occurring over the age of 60 , that is, elderly-onset psoriasis, report differences in clinical patterns and pathogenesis in comparison with 
psoriasis with earlier onset $(28,29)$. Also, given the frequently present comorbidity in elderly psoriasis patients, taking some drugs (lithium, synthetic antimalarial drugs, nonsteroidal anti-inflammatory drugs, tetracyclines, interferons, terbinafine, etc.) can exacerbate pre-existing psoriatic lesions or induce new lesions $(30,31)$.

As for psoriatic arthritis, elderly patients encompass those with elderly-onset psoriatic arthritis ( $>60$ years), but also those with earlier disease onset who entered old age $(32,33)$. A more severe onset of psoriatic arthritis was reported in patients with elderly-onset than in patients with younger-onset psoriatic arthritis, as demonstrated by a greater number of active joints, foot bone erosions and greater inflammatory markers, including C-reactive protein and erythrocyte sedimentation rate (32). Furthermore, a more evident disease progression and activity and worse functional outcome were found in psoriatic arthritis patients with elderly onset than in those with younger onset $(32,33)$. A more severe onset and poorer outcome in patients with elderly-onset psoriatic arthritis may be associated with higher concentrations of IL- $1 \beta$ and IL- 6 found in the synovial fluid of the affected knees in elderly-onset patients, compared to the concentrations of these interleukins in the synovial fluid of the same affected joints in younger-onset psoriatic arthritis patients (32).

Targeting interleukins, a type of cytokine that binds to its receptor on target cells and influences immune response (34), has proved to be beneficial in various diseases, including rheumatoid arthritis (IL-10, IL-11, anti-IL-1, anti-IL-6) and psoriasis (IL-10, IL-11, anti-IL-12, anti-IL-23, anti-IL-17) (35-37). Pharmacotherapy research in elderly population is challenging. The measurement of outcomes, analytical plan and study implementation issues are stumbling blocks in obtaining relevant data in drug efficacy and safety studies in the geriatric population (38). Aging is a complex process that involves alterations in physical, psychological, and social factors. The implications of these changes are numerous and diverse, and may affect susceptibility to disease, its clinical and laboratory manifestations, but also, efficacy, tolerability, and safety of therapy (39). Moreover, these age-related changes may generate obstacles for the enrollment of elderly in clinical trials, especially the frail ones, and for conducting controlled trial in elderly population. Namely, limited cognitive and physical reserve, communication issues (hearing or vision difficulties), multiple comorbidities, polypharmacy, increased susceptibility to infection, medication nonadherence are just some of the challenges of conducting a clinical trial in elderly population $(38,40-42)$. However, except patient-related barriers to enrollment of elderly subjects in a clinical trial of a novel treatment, physician- and trial-related barriers have also been identified, but possible solutions for these issues have been suggested as well $(40,41)$. Although the elderly patients were included in the pivotal clinical trials for interleukin inhibitors reviewed here, the number of subjects aged 65 years and older was often not sufficient to determine whether they responded differently from younger subjects (43-48).

Age-related physiological and functional alterations cause changes in the pharmacokinetics and pharmacodynamics of drugs $(49,50)$. Pharmacodynamics has been less studied than pharmacokinetics in geriatric population (50), and data on 
pharmacodynamic properties of interleukin inhibitors in geriatric population are scarce. Also, it should be borne in mind that biologics often exhibit unique pharmacokinetic and pharmacodynamic properties, which are different from those of small-molecule drugs (51), and that if monoclonal antibodies are considered, such properties depend on monoclonal antibody structure and target antigen (52).

This review focuses on the effectiveness and safety of interleukin inhibitors used in elderly patients with rheumatoid arthritis, psoriasis, and psoriatic arthritis.

\section{Regulatory framework for the enrollment of geriatric subjects in clinical trials}

The guideline entitled: "ICH E7 Studies in support of special populations: geriatrics" (published in 1994), that addresses clinical evaluation of medicinal products in geriatric population, was prepared under the auspices of the International Conference on Harmonisation of Technical Requirements for Registration of Pharmaceuticals for Human Use (ICH) (53). The ICH E7 guideline was revised, resulting in an addendum, published in 2010, that answered questions addressed in the note for guidance on ICH E7 (54). These guidelines recommended that drugs should be studied in all age groups, including elderly, and that the population enrolled in clinical trials should be representative of the target patient population. The addendum to $\mathrm{ICH}$ E7 advocates the enrollment of more than 100 geriatric patients in the Phase 2 and 3 databases, for drugs used in diseases not unique to, but present in the elderly, and that in the marketing application, data should be presented for various age groups (for example $<65,65-74$, 75-84 and >85) (54). Furthermore, the European Medicines Agency (EMA) published the Geriatric Medicines Strategy in 2011 and established the Geriatric Expert Group to assist in the implementation of this strategy $(55,56)$. The Geriatric Expert Group performed an analysis of the available instruments/methods for the characterization of frailty status and the result of this work was Points to consider on frailty: Evaluation instruments for baseline characterization of clinical trial populations (57).

\section{Age-related changes of interleukins}

Monoclonal antibodies target those components of the immune system whose dysregulation has occurred within a specific disorder. However, the biological process of aging itself brings various alterations to the immune system that affect both its innate and acquired compartments $(58,59,60)$. The entire immune system, including immune cells, lymphoid organs, and soluble molecules, is affected by aging $(58,61)$. These changes do not necessarily result in reduced functions of the immune system, but, more precisely, in their modification $(61,62)$. Chronic, low-grade inflammation, which develops with aging, involves elevated circulating levels of IL-1, IL-6, and tumor necrosis factor (TNF)- $\alpha$ $(63,64,65)$. In addition to the reported positive correlation between IL-6 plasma levels and age (65), IL-6 has been recognized as an important predictor of adverse outcomes and mortality in the elderly population (66). It has been shown that the frequency of T helper (Th) 17 cells, major source of IL-17 (67), was lower in peripheral blood of 
healthy elderly subjects ( $\geq 65$ years) than in younger subjects ( $\leq 40$ years), probably due to a decreased frequency of Th17 cells among memory CD4+ T cells (68). Also, the production of IL-17 by the stimulated T cells was significantly lower for healthy old than young men (69). In subjects over 75 years, poor nutritional status and frailty were associated with decreased IL-12p70 and IL-23 production (70).

\section{Pharmacokinetic and pharmacodynamic interactions of interleukin inhibitors with pharmacological treatment of comorbid diseases in elderly patients}

Coexisting chronic disease/s can affect the clinical course of the primary disease, as well as the safety and efficacy of the applied therapy. Two or more chronic diseases are often present in the elderly $(71,72)$. Almost half of the elderly population ( $\geq 65$ years) in the United States have three or more chronic diseases (72). The leading chronic conditions are cardiovascular diseases, chronic respiratory diseases, metabolic syndrome, and tumors $(71,72)$. The most significant common risk factors for these disorders are smoking and obesity, which are also associated with low-grade, chronic inflammation $(73,74)$. Furthermore, the elderly population use almost one-third of all drugs (75).

Considering that the disposition of interleukin inhibitors, which are monoclonal antibodies, is not mediated by any of the microsomal cytochrome (CYP) P450 enzymes or chemical drug transporters, no direct competition of interleukin inhibitors and small molecule drugs would be expected when co-administered (76). Nevertheless, monoclonal antibodies, that specifically block cytokines may exhibit an indirect effect on drug metabolism in liver. More precisely, it has been demonstrated that certain cytokines inhibit CYP450 enzymes, but also have an impact on the expression of transporters of small molecule drugs $(76,77)$. Proinflammatory cytokines, such as IL-1 $\beta$, IL-6 and TNF- $\alpha$, have been observed to downregulate CYP450 enzymes in hepatocytes (78), presumably via NO synthesis (79). Accordingly, tocilizumab, a humanized anti-IL-6 receptor monoclonal antibody that hinders IL-6 binding to its receptor (80), increased CYP3A4 activity in patients with rheumatoid arthritis (81). Consequently, plasma levels of simvastatin (CYP3A4 substrate) in patients with rheumatoid arthritis, previously augmented due to IL-6 induced inhibition of CYP3A4, were reduced to levels detected in healthy individuals one week after tocilizumab infusion (81). Also, tocilizumab enhances the clearance of CYP1A2 and 2C9 substrates (76). On the other hand, the clearance of monoclonal antibodies may be affected by immunosuppressive medications, such as methotrexate, azathioprine and mercaptopurine, presumably by reducing the synthesis of immunoglobulin $\mathrm{G}$ antibodies against these therapeutic monoclonal antibodies $(82,83)$. Finally, altering the expression of the target molecule of monoclonal antibody is also a way in which small molecule drugs can influence the clearance of monoclonal antibodies (76). Overall, the development of an adequate therapeutic approach in the treatment of elderly patients with complex comorbidity requires consideration of potential monoclonal antibodies - small molecule drug interactions. 
Elderly patients with rheumatoid arthritis or psoriasis are often undertreated $(14,42)$, and this is partly due to physician reluctance to include biological treatment (20). The causes underlying this avoidance are a lack of data, concerns about adverse effects, multiple comorbidities, possible interactions with other drugs or poor adherence in elderly patients. Given that clinical trials of biological drugs often involve elderly patients, especially those with comorbidities present, in numbers insufficient to derive relevant conclusions, and that elderly patients are the majority users of many drugs treating chronic conditions, it is crucial to conduct clinical trials to evaluate the efficacy and safety of biological drugs in the population of elderly patients.

\section{Efficacy and safety of interleukin inhibitors in elderly patients with rheumatoid arthritis}

Interleukin inhibitors, which act as antagonists of IL-6 receptor, tocilizumab and sarilumab, were approved for adult patients with moderately to severely active rheumatoid arthritis who have had an inadequate response to one or more diseasemodifying antirheumatic drugs (DMARDS) (84-87). Sirukumab, human monoclonal antibody, that selectively blocks circulating IL-6 was rejected for approval by the US Food and Drug Administration (FDA), due to uncertainty regarding the safety profile (88). Anakinra, a recombinant form of naturally occuring IL-1 receptor antagonist, which binds to the IL- 1 type I receptor, antagonizing the effects of both IL-1 $\alpha$ and IL-1 $\beta(89,90)$, was approved by FDA in 2001 (91), but wasn't included in the 2015 American College of Rheumatology (ACR) guideline for the treatment of rheumatoid arthritis, due to its infrequent use in rheumatoid arthritis and lack of new data since 2012 (92). Also, anakinra is not included in the European League Against Rheumatism (EULAR) recommendations for the management of rheumatoid arthritis with synthetic and biological diseasemodifying antirheumatic drugs: 2019 update (93).

Tocilizumab, a humanized anti-human IL-6 receptor monoclonal antibody, inhibits IL-6 signaling through both soluble and membrane-bound IL-6 receptors (94). In addition to the abovementioned indication, in the European Union (EU) tocilizumab can be used in the treatment of severe, active and progressive rheumatoid arthritis in adults not previously treated with methotrexate $(95,96)$. In patients with rheumatoid arthritis tocilizumab is administered intravenously or subcutaneously, at a recommended (in the $\mathrm{EU}$ ) dose of $8 \mathrm{mg} / \mathrm{kg}$ body weight, given once every four weeks or $162 \mathrm{mg}$ once weekly, respectively $(95,96)$. Pers et al. (2015) compared the efficacy and safety of tocilizumab in patients with rheumatoid arthritis in two age groups, over 65 years $(n=61)$, and under 65 years $(n=161)(97)$. The patients enrolled in this study received usual tocilizumab dose of $8 \mathrm{mg} / \mathrm{kg}$ every four weeks (97). The efficacy of tocilizumab after 6 months of treatment was assessed according to EULAR response criteria (98). Good EULAR response was lower in elderly than in younger patients $(40.7 \%$ vs $61 \%$; $p=0.001)(97)$. On the other hand, there was no difference in moderate EULAR response between age groups. Also, remission was less frequently achieved in elderly patients compared to younger patients with rheumatoid arthritis (97). Regarding the safety of tocilizumab, no difference in 
adverse events discontinuation rates between elderly and younger rheumatoid arthritis patients was detected (97). However, the authors do not rule out the possibility that tocilizumab was prescribed mainly to those elderly patients with better general health condition. ICHIBAN, a prospective study that assessed long-term effectiveness and safety of tocilizumab among patients with rheumatoid arthritis in daily German practice, showed similar efficacy of tocilizumab therapy in all examined age groups $(<50,50-65$, and $>65$ years). Furthermore, adverse effects discontinuation rates and incidence of infections did not significantly change with age $(99,100)$.

Sarilumab is a human mononoclonal antibody directed against the IL-6 receptor alpha, membrane-bound or soluble forms, with greater relative binding affinity for the target receptor than tocilizumab $(101,102)$. Moreover, in comparison with tocilizumab, it inhibits IL-6 induced cellular response at lower concentrations (102). Sarilumab is administered as a subcutaneous injection in the recommended dose of $200 \mathrm{mg}$ once every two weeks $(86,87)$. A pooled exploratory analysis from MOBILITY and TARGET trials, evaluating efficacy and safety of sarilumab in rheumatoid arthritis patients aged 65 years and above and in rheumatoid arthritis patients under 65 years, showed comparable efficacy of sarilumab (150 and $200 \mathrm{mg}$ ) between two age groups according to ACR 20 response rates, Disease Activity Score in 28 joints using C-reactive protein (DAS28CRP) remission rates, at week 24, improvement from baseline in DAS28-CRP and clinical disease activity index (CDAI) at week 24, and according to change in physical function from baseline assessed by the Health Assessment Questionnaire-Disability Index (HAQ-DI) at week 12 (103). Severe adverse events, such as severe infections, developed more frequently in rheumatoid arthritis patients aged 65 years and above than in younger patients (103).

\section{Efficacy and safety of interleukin inhibitors in elderly patients with psoriasis and psoriatic arthritis}

The interleukin inhibitors, from the biologics armamentarium for psoriasis and psoriatic arthritis, targeted against cytokines pivotal for the immunopathogenesis of psoriasis and psoriatic arthritis, or against their receptors, are IL-12/23 and IL-17 inhibitors $(104,105)$. Also, biologics aiming p19 subunit of IL-23 were shown to be efficient in the treatment of psoriasis (104).

Ustekinumab is a human monoclonal antibody that targets the p40 subunit shared by both cytokines IL-12 and IL-23 (106). It is approved for the treatment of moderate-tosevere plaque psoriasis, but also for the treatment of psoriatic arthritis in adults $(107,108)$. In elderly patients with psoriasis $(n=24)$, the safety and efficacy of ustekinumab was assessed over a period of one year (109). Ustekinumab was administered subcutaneously at recommended dosage. The most frequent comorbidities among patients were cardiovascular diseases (62.5\%). Also, metabolic disorders (37.5\%), latent tuberculosis $(29.2 \%)$ and other comorbidities were present in these patients. The efficacy was evaluated on the basis of Psoriasis Area and Severity Index (PASI) and the Dermatology Life Quality Index (DLQI). Given the proportion of patients that had $75 \%$ or more 
reduction in PASI score (PASI 75) in the patient group that had received ustekinumab treatment before other biologics, and in the patient group that hadn't been previously treated with biologics, a significantly greater improvement was reported in the latter group (109). Taking into account the total number of patients enrolled, PASI 75 was achieved in $60 \%$ at week 52 (109). However, ustekinumab treatment showed to be efficient in elderly psoriasis patients, and at the same time no severe adverse events were detected (109). Megna et al. (2016) performed a retrospective study of the efficacy and safety of ustekinumab in elderly patients $(n=22)$ over a two-year period, and they obtained results similar to the ones previously described (110). Namely, PAS 75 was reached in $86.4 \%$ of patients at week 52 and in $90.9 \%$ of patients at week 100 . Moreover, the twoyear period of ustekinumab treatment was without severe adverse events (110). Therefore, even though these studies did not encompass such a large number of elderly psoriasis patients, the results suggested that ustekinumab may be considered a preferable agent for elderly psoriasis patients. As regards the use of ustekinumab in the treatment of elderly patients with psoriatic arthritis, relevant data were obtained from the PsaBio study (111). The PsaBio study was undertaken in order to collect data on patients with psoriatic arthritis receiving either ustekinumab or TNF inhibitors as first, second or third line of biologic DMARD treatment, and included 458 patients with psoriatic arthritis, of whom $22.9 \%$ were aged 60 years and older $(111,112)$. Gossec et al. (2020) reported PsaBio results related to the comparison of the efficacy and safety of ustekinumab therapy, maintained from 6 to 12 months, between elderly and younger patients. Actually, the effectiveness and safety of ustekinumab therapy were comparable between two age groups (112).

The approved indications for secukinumab, human monoclonal anti-IL-17A antibody, are moderate to severe plaque psoriasis, active psoriatic arthritis, and active ankylosing spondylitis in adult patients $(43,113)$. The results from two-year retrospective observational study by Megna et al. (2020) showed that treatment with secukinumab in patients with psoriasis age 65 or older was effective, judging by the significant reduction of PASI and body surface area (BSA) (114). The final mean PASI and BSA reduction was $85.1 \%$ and $88 \%$, respectively (114). Secukinumab treatment was discontinued by 6 patients of a total number of 29 patients enrolled in this study, and in most cases the discontinuation was due to loss of response during the treatment. Furthermore, no severe adverse effects were reported during the two years covered by the study (114). A pooled post-hoc analysis of three phase III trials (ERASURE, FIXTURE and CLEAR) was performed in order to assess the efficacy and safety profile of this monoclonal anti-IL-17A antibody in elderly patients with moderate to severe plaque psoriasis (115). According to PASI and DLQI, this monoclonal anti-IL-17A antibody was found to be efficient in elderly patients. Moreover, the observed efficacy was comparable between elderly $(\mathrm{n}=67)$ and younger patients $(\mathrm{N}=841)$. More precisely, PAS 75 was achieved by $81.8 \%$ of elderly psoriasis patients and $79.4 \%$ of patients younger than 65 years by week 52 (115). Secukinumab administered at a recommended dose of $300 \mathrm{mg}$ subcutaneously showed no difference in the total rate of adverse events in elderly and younger patients. 
Nevertheless, the occurrence of severe adverse events, which were most likely related to secukinumab treatment, was higher in elderly patients (4.5\% vs $1.8 \%)$, and these patients more frequently discontinued treatment compared to younger patients $(7.5 \%$ vs $1.8 \%)$ (115). The results of long-term studies demonstrated a favorable efficacy and safety profile of secukinumab in the treatment of psoriatic arthritis $(116,117)$, but, to the best of our knowledge, there are no studies that analyze the efficacy and safety profile of this interleukin inhibitor in elderly patients with psoriatic arthritis.

After secukinumab, another IL-17A inhibitor, ixekizumab, was approved for the treatment of moderate to severe plaque psoriasis and active psoriatic arthritis $(45,118)$. Ixekizumab is a humanized monoclonal antibody directed against IL-17A (119), which is believed to be the key effector cytokine in the patogenesis of psoriasis $(120,121)$. A retrospective real-life study of the efficacy and safety of ixekizumab over a one-year period included 16 elderly ( $\geq 65$ years) psoriasis patients (122). Psoriatic arthritis as a comorbidity was present in 9 patients. Moreover, most of these patients $(n=14)$ had been previously treated with biologics (122). A remarkable improvement was found in these patients, judging by PASI 75 achieved by $93.7 \%$ at week 12 , and by $100 \%$ improvement in PASI score (PASI 100) achieved by $81.2 \%$ at week 48 (122). Throughout the observed treatment period, no serious adverse events were reported, although one patient discontinued the therapy because of inadequate control of psoriatic arthritis (122).

Brodalumab is a human monoclonal antibody with high affinity to the IL-17 receptor A (123), approved for the treatment of moderate to severe plaque psoriasis in adults $(44,124)$. In a pooled analysis, the data from phase III studies AMAGINE-1 and AMAGINE-2, undertaken to assess the safety and efficacy of brodalumab at two different doses $(140 \mathrm{mg}$ and $210 \mathrm{mg})(125,126)$ were stratified by two age groups $(<65$ and $\geq 65$ years) (127). The patients received brodalumab every 2 weeks (140 $\mathrm{mg}$ or $210 \mathrm{mg}$ ), ustekinumab according to labeled dosing regimen, or placebo (127). The effectiveness of the treatment was assessed by PASI score and static physician's global assessment (sPGA). The response rates of PASI 100 from baseline in elderly and younger psoriasis patients receiving brodalumab were $56.9 \%$ and $58.1 \%$, respectively, at week 120 . Similarly, taking into account the sPGA score, a comparable efficacy of brodalumab was found among elderly and younger psoriasis patients. Also, no difference in treatmentemergent adverse events rates between these two age groups was detected (127). A longterm evaluation of the efficacy and safety of modern treatments for psoriasis, that included 154 patients of Greek origin aged 65 years and older, showed a fast efficacy according to PASI 75 and 90\% reduction in PASI score (PASI 90) response rates, but also sustained efficacy of brodalumab, secukinumab and ustekinumab (128). In fact, 16 patients had brodalumab treatment, and all of them achieved PASI 75 at week 12, and PASI 90 at week 24, and this efficacy of brodalumab was maintained for up to three years (128).

Guselkumab is a human monoclonal antibody, and tildrakizumab and risankizumab are humanized monoclonal antibodies, that selectively bind p19 subunit of IL-23, blocking its action on the IL-23 receptor (129). Guselkumab, tildrakizumab and 
risankizumab were approved by FDA in 2017, 2018 and 2019, respectively, for the treatment of moderate to severe plaque psoriasis $(46,47,48)$. Real-life studies of efficacy and safety of these IL-23p19 antagonists in elderly patients are lacking. The package insert of the drug reports that a total of $185 / 3406$ subjects with plaque psoriasis or psoriatic arthritis exposed to the guselkumab in clinical trials were 65 years or older and 13 subjects were 75 years or older (46). As for tildrakizumab, the package insert of the drug reports that a total of $92 / 1083$ subjects exposed to this IL-23p19 antagonist in clinical trials were 65 years and older, and 17 subjects were 75 years and older (47). When it comes to risankizumab, a total of 243/2234 subjects with plaque psoriasis exposed to this drug in clinical trials were 65 years and older, and 24 subjects were 75 years and older (48). The efficacy and safety profiles of all three IL-23p19 antagonists were comparable between elderly and younger subjects $(46,47,48)$.

\section{Conclusion}

Although most of the reviewed findings may be limited by sample sizes, they suggest that interleukin inhibitors approved and currently in use in clinical practice for the treatment of rheumatoid arthritis, psoriasis, and psoriatic arthritis can be considered a safe and efficient option for these diseases in elderly patients. Bearing in mind that these diseases with elderly-onset have, to some extent, different characteristics than when they start earlier, such as clinical and laboratory manifestations, and possibly differences in genetic background and immunopathogenesis, studies are required to assess the efficacy and safety of interleukin inhibitors specifically in these patients.

\section{References}

1. United Nations, Department of Economic and Social Affairs, Population Division (2019). World Population Prospects 2019: Highlights. ST/ESA/SER.A/423. Available from: https://population.un.org/wpp/Publications/Files/WPP2019_Highlights.pdf.

2. Smolen JS, Aletaha D, McInnes IB. Rheumatoid arthritis. Lancet. 2016;22;388(10055):2023-2038. Erratum in: Lancet. 2016 Oct 22;388(10055):1984.

3. Takeshita J, Grewal S, Langan SM, Mehta NN, Ogdie A, Van Voorhees AS, et al. Psoriasis and comorbid diseases: Epidemiology. J Am Acad Dermatol. 2017;76(3):377-390.

4. Rachakonda TD, Schupp CW, Armstrong AW. Psoriasis prevalence among adults in the United States. J Am Acad Dermatol. 2014;70(3):512-6.

5. Guo Q, Wang Y, Xu D, Nossent J, Pavlos NJ, Xu J. Rheumatoid arthritis: pathological mechanisms and modern pharmacologic therapies. Bone Res. 2018;27;6:15.

6. Reich $\mathrm{K}$. The concept of psoriasis as a systemic inflammation: implications for disease management. J Eur Acad Dermatol Venereol. 2012;26 Suppl 2:3-11. 
7. Kim WB, Jerome D, Yeung J. Diagnosis and management of psoriasis. Can Fam Physician. 2017;63(4):278-285.

8. Ogdie A, Weiss P. The epidemiology of psoriatic arthritis. Rheum Dis Clin N Am. 2015;41:545-68.

9. Mease PJ, Gladman DD, Papp KA, Khraishi MM, Thaçi D, Behrens F, et al. Prevalence of rheumatologist-diagnosed psoriatic arthritis in patients with psoriasis in European/North American dermatology clinics. J Am Acad Dermatol. 2013 Nov;69(5):729-735.

10. Haroon M, Kirby B, Fitzgerald O. High prevalence of psoriatic arthritis in patients with severe psoriasis with suboptimal performance of screening questionnaires. Ann Rheum Dis. 2013;72:736-40.

11. Gladman DD, Antoni C, Mease P, Clegg DO, Nash P. Psoriatic arthritis: epidemiology, clinical features, course, and outcome. Ann Rheum Dis. 2005;64 Suppl 2(Suppl 2):ii14-7.

12. Rasch EK, Hirsch R, Paulose-Ram R, Hochberg MC. Prevalence of rheumatoid arthritis in persons 60 years of age and older in the United States: effect of different methods of case classification. Arthritis Rheum. 2003;48(4):917-26.

13. Olivieri I, Palazzi C, Peruz G, Padula A. Management issues with elderly-onset rheumatoid arthritis: an update. Drugs Aging. 2005;22(10):809-22.

14. Tutuncu Z, Reed G, Kremer J, Kavanaugh A. Do patients with older-onset rheumatoid arthritis receive less aggressive treatment? Ann Rheum Dis. 2006;65(9):1226-9.

15. Kobak S, Bes C. An autumn tale: geriatric rheumatoid arthritis. Ther Adv Musculoskelet Dis. 2018;10(1):3-11.

16. Innala L, Berglin E, Möller B, Ljung L, Smedby T, Södergren A, et al. Age at onset determines severity and choice of treatment in early rheumatoid arthritis: a prospective study. Arthritis Res Ther. 2014;16(2):R94.

17. Huscher D, Sengler C, Gromnica-Ihle E, Bischoff S, Eidner T, Ochs W, et al. Clinical presentation, burden of disease and treatment in young-onset and late-onset rheumatoid arthritis: a matched-pairs analysis taking age and disease duration into account. Clin Exp Rheumatol. 2013;31(2):256-62.

18. Radovits BJ, Fransen J, Eijsbouts A, van Riel PL, Laan RF. Missed opportunities in the treatment of elderly patients with rheumatoid arthritis. Rheumatology (Oxford). 2009;48:906-910.

19. Schmajuk G, Schneeweiss S, Katz JN, Weinblatt ME, Setoguchi S, Avorn J, et al. Treatment of older adult patients diagnosed with rheumatoid arthritis: improved but not optimal. Arthritis Rheum. 2007;57:928-934.

20. Fraenkel L, Rabidou N, Dhar R. Are rheumatologists' treatment decisions influenced by patients' age? Rheumatology (Oxford). 2006;45:1555-1557.

21. Punzi L, Bertazzolo N, Pianon M, Rizzi E, Rossini P, Todesco S. Synovial fluid levels of proinflammatory interleukins and their inter-relationships in elderly vs younger onset rheumatoid arthritis. Aging (Milano). 1996;8(4):277-81.

22. Treharne GJ, Douglas KM, Iwaszko J, Panoulas VF, Hale ED, Mitton DL, et al. Polypharmacy among people with rheumatoid arthritis: the role of age, disease duration and comorbidity. Musculoskeletal Care. 2007;5(4):175-90.

23. Kievit W, van Hulst L, van Riel P, Fraenkel L. Factors that influence rheumatologists' decisions to escalate care in rheumatoid arthritis: results from a choice-based conjoint analysis. Arthritis Care Res (Hoboken). 2010;62(6):842-7. 
24. Theodorakopoulou E, Yiu ZZ, Bundy C, Chularojanamontri L, Gittins M, Jamieson LA, et al. Earlyand late-onset psoriasis: a cross-sectional clinical and immunocytochemical investigation. $\mathrm{Br} \mathrm{J}$ Dermatol. 2016;175(5):1038-1044. doi: 10.1111/bjd.14886.

25. Queiro R, Tejón P, Alonso S, Coto P. Age at disease onset: a key factor for understanding psoriatic disease. Rheumatology (Oxford). 2014;53(7):1178-85.

26. Allen MH, Ameen H, Veal C, Evans J, Ramrakha-Jones VS, Marsland AM, et al. The major psoriasis susceptibility locus PSORS1 is not a risk factor for late-onset psoriasis. J Invest Dermatol. 2005;124(1):103-6.

27. Hébert HL, Bowes J, Smith RL, McHugh NJ, Barker JNWN, Griffiths CEM, et al. Polymorphisms in IL-1B distinguish between psoriasis of early and late onset. J Invest Dermatol. 2014;134(5):14591462.

28. Kwon HH, Kwon IH, Youn JI. Clinical study of psoriasis occurring over the age of 60 years: is elderly-onset psoriasis a distinct subtype? Int J Dermatol. 2012;51(1):53-8.

29. Phan C, Sigal ML, Estève E, Reguiai Z, Barthélémy H, Beneton N, et al. Psoriasis in the elderly: epidemiological and clinical aspects, and evaluation of patients with very late onset psoriasis. $\mathrm{J}$ Eur Acad Dermatol Venereol. 2016;30(1):78-82.

30. Tsankov N, Irena A, Kasandjieva J. Drug-induced psoriasis: recognition and management. Am J Clin Dermatol. 2000;1:159-165.

31. Kim GK, Del Rosso JQ. Drug-provoked psoriasis: is it drug induced or drug aggravated?: understanding pathophysiology and clinical relevance. J Clin Aesthet Dermatol. 2010;3(1):32-8.

32. Punzi L, Pianon M, Rossini P, Schiavon F, Gambari PF. Clinical and laboratory manifestations of elderly onset psoriatic arthritis: a comparison with younger onset disease. Ann Rheum Dis. 1999;58:226-9.

33. Caso F, Tasso M, Chimenti MS, Navarini L, Perricone C, Girolimetto N, et al. Late-Onset and Elderly Psoriatic Arthritis: Clinical Aspects and Management. Drugs Aging. 2019;36(10):909-925.

34. Magyari L, Varszegi D, Kovesdi E, Sarlos P, Farago B, Javorhazy A, et al. Interleukins and interleukin receptors in rheumatoid arthritis: Research, diagnostics and clinical implications. World J Orthop. 2014;5(4):516-36.

35. Zídek Z, Anzenbacher P, Kmonícková E. Current status and challenges of cytokine pharmacology. Br J Pharmacol. 2009;157(3):342-61.

36. Tsai YC, Tsai TF. Anti-interleukin and interleukin therapies for psoriasis: current evidence and clinical usefulness. Ther Adv Musculoskelet Dis. 2017;9(11):277-294.

37. Yang K, Oak ASW, Elewski BE. Use of IL-23 Inhibitors for the Treatment of Plaque Psoriasis and Psoriatic Arthritis: A Comprehensive Review. Am J Clin Dermatol. 2021;22(2):173-192.

38. Orwig D, Rickles NM, Martin LG. Methodological issues in pharmacotherapy research in older adults. Am J Geriatr Pharmacother. 2011;9(3):173-89.

39. Boots AM, Maier AB, Stinissen P, Masson P, Lories RJ, De Keyser F. The influence of ageing on the development and management of rheumatoid arthritis. Nat Rev Rheumatol. 2013;9(10):604-13.

40. Hempenius L, Slaets JP, Boelens MA, van Asselt DZ, de Bock GH, Wiggers T, et al. Inclusion of frail elderly patients in clinical trials: solutions to the problems. J Geriatr Oncol. 2013;4(1):26-31.

41. Denson AC, Mahipal A. Participation of the elderly population in clinical trials: barriers and solutions. Cancer Control. 2014;21(3):209-14. 
42. Di Lernia V, Goldust M. An overview of the efficacy and safety of systemic treatments for psoriasis in the elderly. Expert Opin Biol Ther. 2018;18(8):897-903.

43. Highlights of prescribing information - Cosentyx (secukinumab) [Internet]. U.S. Food and Drug administration [cited 2021 Mar 31]. Available from:

https://www.accessdata.fda.gov/drugsatfda_docs/label/2016/125504s001s002lbl.pdf.

44. Highlights of prescribing information - Siliq (brodalumab) [Internet]. U.S. Food and Drug administration [cited $2021 \mathrm{Mar} 31$ ]. Available from:

https://www.accessdata.fda.gov/drugsatfda_docs/label/2017/761032lbl.pdf.

45. Highlights of prescribing information - Taltz (ixekizumab) [Internet]. U.S. Food and Drug administration [cited 2021 Mar 31]. Available from:

https://www.accessdata.fda.gov/drugsatfda_docs/label/2016/125521s000lbl.pdf.

46. Highlights of prescribing information - Tremfya (guselkumab) [Internet]. U.S. Food and Drug administration [cited 2021 Mar 31]. Available from:

https://www.accessdata.fda.gov/drugsatfda_docs/label/2017/761061s000lbl.pdf.

47. Highlights of prescribing information - Ilumya (tildrakizumab) [Internet]. U.S. Food and Drug administration [cited $2021 \mathrm{Mar}$ 31]. Available from:

https://www.accessdata.fda.gov/drugsatfda_docs/label/2018/761067s000lbl.pdf.

48. Highlights of prescribing information - Skyrizi (risankizumab) [Internet]. U.S. Food and Drug administration [cited $2021 \mathrm{Mar}$ 31]. Available from:

https://www.accessdata.fda.gov/drugsatfda_docs/label/2019/761105s000lbl.pdf.

49. Sera LC, McPherson ML. Pharmacokinetics and pharmacodynamic changes associated with aging and implications for drug therapy. Clin Geriatr Med. 2012;28(2):273-86.

50. De Spiegeleer B, Wynendaele E, Bracke N, Veryser L, Taevernier L, Degroote A, et al. Regulatory development of geriatric medicines: To GIP or not to GIP? Ageing Res Rev. 2016;27:23-36.

51. Meibohm B. The Role of Pharmacokinetics and Pharmacodynamics in the Development of Biotech Drugs. In: Meibohm B, editor. Pharmacokinetics and Pharmacodynamics of Biotech Drugs: Principles and Case Studies in Drug Development. Weinheim: WILEY-VCH Verlag GmbH \& Co; 2006; p. 1-13.

52. Mould DR, Green B. Pharmacokinetics and pharmacodynamics of monoclonal antibodies: concepts and lessons for drug development. BioDrugs. 2010;24(1):23-39.

53. ICH Topic E 7 Studies in Support of Special Populations: Geriatrics [Internet]. European Medicines Agency [cited 2021 Mar 31]. Available from: https://www.ema.europa.eu/en/documents/scientificguideline/ich-e-7-studies-support-special-populations-geriatrics-step-5_en.pdf.

54. ICH topic E7 Studies in Support of Special Populations: Geriatrics Questions and Answers [Internet]. European Medicines Agency [cited 2021 Mar 31]. Available from:

https://www.ema.europa.eu/en/documents/scientific-guideline/ich-e-7-studies-support-specialpopulations-geriatrics-questions-answers-step-5_en.pdf.

55. EMA geriatric medicines strategy [Internet]. European Medicines Agency [cited 2021 Mar 31]. Available from:

https://www.ema.europa.eu/en/documents/other/geriatric-medicines-strategy_en.pdf. 
56. EMA geriatric medicines strategy [Internet]. European Medicines Agency [cited 2021 Mar 31]. Available from:

https://www.ema.europa.eu/en/documents/other/mandate-objectives-rules-procedure-chmpgeriatric-expert-group_en.pdf.

57. Points to consider on frailty: Evaluation instruments for baseline characterisation of clinical trial populations [Internet]. European Medicines Agency [cited 2021 Mar 31]. Available from: https://www.ema.europa.eu/en/documents/scientific-guideline/draft-points-consider-frailtyevaluation-instruments-baseline-characterisation-clinical-trial_en.pdf.

58. Nikolich-Žugich J. The twilight of immunity: emerging concepts in aging of the immune system. Nat Immunol. 2017;19(1):10-19.

59. Müller L, Pawelec G. As we age: Does slippage of quality control in the immune system lead to collateral damage? Ageing Res Rev. 2015;23(Pt A):116-23.

60. Nikolich-Žugich J. Aging of the T cell compartment in mice and humans: from no naive expectations to foggy memories. J Immunol. 2014;193(6):2622-9.

61. Müller L, Di Benedetto S, Pawelec G. The immune system and its dysregulation with aging. Subcell Biochem. 2019;91:21-43.

62. Burkle A, Caselli G, Franceschi C, Mariani E, Sansoni P, Santoni A, et al. Pathophysiology of ageing, longevity and age related diseases. Immun Ageing 2007;4:4.

63. Franceschi C, Garagnani P, Parini P, Giuliani C, Santoro A. Inflammaging: a new immune-metabolic viewpoint for age-related diseases. Nat Rev Endocrinol. 2018;14(10):576-590.

64. Milan-Mattos JC, Anibal FF, Perseguini NM, Minatel V, Rehder-Santos P, Castro CA, et al. Effects of natural aging and gender on pro-inflammatory markers. Braz J Med Biol Res. 2019;52(9):e8392.

65. Alvarez-Rodríguez L, López-Hoyos M, Muãoz-Cacho P, Martínez-Taboada VM. Aging is associated with circulating cytokine dysregulation. Cell Immunol. 2012;273:124-132.

66. Varadhan R, Yao W, Matteini A, Beamer BA, Xue QL, Yang H, et al. Simple biologically informed inflammatory index of two serum cytokines predicts 10 year all-cause mortality in older adults. $\mathrm{J}$ Gerontol A Biol Sci Med Sci. 2014;69:165-73.

67. Jin W, Dong C. IL-17 cytokines in immunity and inflammation. Emerg Microbes Infect. 2013;2(9):e60.

68. Lee JS, Lee WW, Kim SH, Kang Y, Lee N, Shin MS, et al. Age-associated alteration in naive and memory Th17 cell response in humans. Clin Immunol. 2011;140(1):84-91.

69. Goetzl EJ, Huang MC, Kon J, Patel K, Schwartz JB, Fast K, et al. Gender specificity of altered human immune cytokine profiles in aging. FASEB J. 2010;24(9):3580-9.

70. Compté N, Zouaoui Boudjeltia K, Vanhaeverbeek M, De Breucker S, Tassignon J, Trelcat A, et al. Frailty in old age is associated with decreased interleukin-12/23 production in response to toll-like receptor ligation. PLoS One. 2013;8(6):e65325.

71. Fabbri LM, Ferrari R. Chronic disease in the elderly: back to the future of internal medicine. Breathe 2006;3(1):40-49.

72. Boyd CM, Darer J, Boult C, Fried LP, Boult L, Wu AW. Clinical practice guidelines and quality of care for older patients with multiple comorbid diseases: implications for pay for performance. JAMA 2005;294:716-724. 
73. Poirier P, Giles TD, Bray GA, Hong Y, Stern JS, Pi-Sunyer FX, et al. Obesity and cardiovascular disease: pathophysiology, evaluation, and effect of weight loss: an update of the 1997 American Heart Association Scientific Statement on Obesity and Heart Disease from the Obesity Committee of the Council on Nutrition, Physical Activity, and Metabolism. Circulation. 2006;113(6):898-918.

74. Rempher KJ. Cardiovascular sequelae of tobacco smoking. Crit Care Nurs Clin North Am. 2006;18:13-20.

75. Shenoy P, Harugeri A. Elderly patients' participation in clinical trials. Perspect Clin Res. 2015;6(4):184-9.

76. Ferri N, Bellosta S, Baldessin L, Boccia D, Racagni G, Corsini A. Pharmacokinetics interactions of monoclonal antibodies. Pharmacol Res. 2016;111:592-599.

77. Zhou H, Mascelli MA. Mechanisms of monoclonal antibody-drug interactions. Annu Rev Pharmacol Toxicol. 2011;51:359-72.

78. Aitken AE, Morgan ET. Gene-specific effects of inflammatory cytokines on cytochrome P450 2C, 2B6 and 3A4 mRNA levels in human hepatocytes. Drug Metab Dispos. 2007;35:1687-93.

79. Khatsenko OG, Gross SS, Rifkind AB, Vane J. Nitric oxide is a mediator of the decrease in cytochrome P450-dependent metabolism caused by immunostimulants. Proc Natl Acad Sci. USA 1993;90:11147-51.

80. Sebba A. Tocilizumab: the first interleukin-6-receptor inhibitor. Am J Health Syst Pharm. 2008;65(15):1413-8.

81. Schmitt C, Kuhn B, Zhang X, Kivitz AJ, Grange S. Disease-drug-drug interaction involving tocilizumab and simvastatin in patients with rheumatoid arthritis. Clin Pharmacol Ther. 2011;89(5):735-40.

82. Baert F, Noman M, Vermeire S, Van Assche G, D' Haens G, Carbonez A, et al. Influence of immunogenicity on the long-term efficacy of infliximab in Crohn's disease. N Engl J Med. 2003;348(7):601-8.

83. Seitz K, Zhou H. Pharmacokinetic drug-drug interaction potentials for therapeutic monoclonal antibodies: reality check. J Clin Pharmacol. 2007;47(9):1104-18.

84. Highlights of prescribing information - Actemra (tocilizumab) [Internet]. U.S. Food and Drug administration [cited 2021 Mar 31]. Available from: https://www.accessdata.fda.gov/drugsatfda_docs/label/2017/125276s114lbl.pdf.

85. European Medicines Agency [Internet]. [cited 2021 Mar 31]. Available from: https://www.ema.europa.eu/en/medicines/human/EPAR/roactemra\#authorisation-details-section.

86. Highlights of prescribing information - Kevzara (sarilumab) [Internet]. U.S. Food and Drug administration [cited 2021 Mar 31]. Available from: https://www.accessdata.fda.gov/drugsatfda_docs/label/2017/761037s000lbl.pdf.

87. European Medicines Agency [Internet]. [cited 2021 Mar 31]. Available from: https://www.ema.europa.eu/en/medicines/human/EPAR/kevzara\#authorisation-details-section.

88. U.S. Food and Drug administration [Internet]. [cited 2021 Mar 31]. Available from: https://www.fda.gov/media/107409/download.

89. Baskar S, Klein AL, Zeft A. The Use of IL-1 Receptor Antagonist (Anakinra) in Idiopathic Recurrent Pericarditis: A Narrative Review. Cardiol Res Pract. 2016;2016:7840724. 
90. Dinarello CA, Simon A, van der Meer JW. Treating inflammation by blocking interleukin-1 in a broad spectrum of diseases. Nat Rev Drug Discov. 2012;11(8):633-52.

91. Highlights of prescribing information - Kineret (anakinra) [Internet]. U.S. Food and Drug administration [cited 2021 Mar 31]. Available from: https://www.accessdata.fda.gov/drugsatfda_docs/label/2012/103950s5136lbl.pdf.

92. Singh JA, Saag KG, Bridges SL Jr, Akl EA, Bannuru RR, Sullivan MC, et al. 2015 American College of Rheumatology Guideline for the Treatment of Rheumatoid Arthritis. Arthritis Rheumatol. 2016;68(1):1-26.

93. Smolen JS, Landewé RBM, Bijlsma JWJ, Burmester GR, Dougados M, Kerschbaumer A, et al. EULAR recommendations for the management of rheumatoid arthritis with synthetic and biological disease-modifying antirheumatic drugs: 2019 update. Ann Rheum Dis. 2020;79(6):685-699.

94. Mihara M, Kasutani K, Okazaki M, Nakamura A, Kawai S, Sugimoto M, et al. Tocilizumab inhibits signal transduction mediated by both mIL-6R and sIL-6R, but not by the receptors of other members of IL-6 cytokine family. Int Immunopharmacol. 2005;5(12):1731-40.

95. Summary of product characteristics - RoActemra (tocilizumab) [Internet]. European Medicines Agency [cited 2021 Mar 31]. Available from: https:/www.ema.europa.eu/en/documents/productinformation/roactemra-epar-product-information_en.pdf.

96. Scott LJ. Tocilizumab: A Review in Rheumatoid Arthritis. Drugs. 2017;77(17):1865-1879.

97. Pers YM, Schaub R, Constant E, Lambert J, Godfrin-Valnet M, Fortunet C, et al. Efficacy and safety of tocilizumab in elderly patients with rheumatoid arthritis. Joint Bone Spine. 2015;82(1):25-30.

98. van Gestel AM, Prevoo ML, van 't Hof MA, van Rijswijk MH, van de Putte LB, van Riel PL. Development and validation of the European League Against Rheumatism response criteria for rheumatoid arthritis. Comparison with the preliminary American College of Rheumatology and the World Health Organization/International League Against Rheumatism Criteria. Arthritis Rheum. 1996;39(1):34-40.

99. Specker C, Kaufmann J, Kellner H, Kästner P, Volberg C, Braunewell V et al. FRI0202 Safe and Effective Tocilizumab Therapy in Elderly Patients with Rheumatoid Arthritis. Ann Rheum Dis. 2016;75:504.

100. Specker C, Alberding A, Aringer M, Burmester GR, Flacke JP, Hofmann MW, et al. ICHIBAN, a non-interventional study evaluating tocilizumab long-term effectiveness and safety in patients with active rheumatoid arthritis. Clin Exp Rheumatol. 2020 Jul 10. Epub ahead of print. PMID: 32662413.

101. June RR, Olsen NJ. Room for more IL-6 blockade? Sarilumab for the treatment of rheumatoid arthritis. Expert Opin Biol Ther. 2016;16(10):1303-9.

102. Rafique A, Martin J, Blome M, Huang A, Ouyang A, Papadopoulos N. Evaluation of the binding kinetics and functional bioassay activity of sarilumab and tocilizumab to the human IL-6 receptor alpha. Ann Rheum Dis. 2014;72:A797.

103. Fleischmann R, Genovese MC, van Adelsberg J, Mangan E, Iglesias-Rodriguez M, Dukovic D, et al. Pooled safety and efficacy of sarilumab in rheumatoid arthritis patients 65 years of age and older [abstract] Arthritis Rheumatol. 2016; 68 (suppl 10).

104. Kamata M, Tada Y. Efficacy and Safety of Biologics for Psoriasis and Psoriatic Arthritis and Their Impact on Comorbidities: A Literature Review. Int J Mol Sci. 2020;21(5):1690. 
105. Jeon C, Sekhon S, Yan D, Afifi L, Nakamura M, Bhutani T. Monoclonal antibodies inhibiting IL12, -23, and -17 for the treatment of psoriasis. Hum Vaccin Immunother. 2017;13(10):2247-2259.

106. McKeage K. Ustekinumab: a review of its use in psoriatic arthritis. Drugs. 2014;74(9):1029-39.

107. Highlights of prescribing information - Stelara (ustekinumab) [Internet]. U.S. Food and Drug administration [cited 2021 Mar 31]. Available from: https://www.accessdata.fda.gov/drugsatfda_docs/label/2019/761044s003lbl.pdf.

108. European Medicines Agency [Internet]. [cited 2021 Mar 31]. Available from: https://www.ema.europa.eu/en/medicines/human/EPAR/stelara\#authorisation-details-section.

109. Hayashi M, Umezawa Y, Fukuchi O, Ito T, Saeki H, Nakagawa H. Efficacy and safety of ustekinumab treatment in elderly patients with psoriasis. J Dermatol. 2014;41(11):974-80.

110. Megna M, Napolitano M, Balato N, Monfrecola G, Villani A, Ayala F, et al. Efficacy and safety of ustekinumab in a group of 22 elderly patients with psoriasis over a 2-year period. Clin Exp Dermatol. 2016;41(5):564-6.

111. A Study on Assessment of STELARA and Tumor Necrosis Factor Alpha Inhibitor Therapies in Participants with Psoriatic Arthritis (PsaBio) [Internet]. [cited 2021 Mar 31]. Available from: https://clinicaltrials.gov/ct2/show/NCT02627768.

112. Gossec L, Theander E, Chakravarty S, Bergmans P, Lin I, Noël W, et al. Ustekinumab-Treated Patients with Psoriatic Arthritis in a Real-world Study: Similar Clinical Responses and Treatment Persistence over One Year in Elderly and Younger Patients [abstract]. Arthritis Rheumatol. 2020; 72 (suppl 10).

113. European Medicines Agency [Internet]. [cited 2021 Mar 31]. Available from: https://www.ema.europa.eu/en/medicines/human/EPAR/cosentyx\#authorisation-details-section

114. Megna M, Camela E, Cinelli E, Fabbrocini G. Real-life efficacy and safety of secukinumab in elderly patients with psoriasis over a 2-year period. Clin Exp Dermatol. 2020;45(7):848-852.

115. Körber A, Papavassilis C, Bhosekar V, Reinhardt M. Efficacy and Safety of Secukinumab in Elderly Subjects with Moderate to Severe Plaque Psoriasis: A Pooled Analysis of Phase III Studies. Drugs Aging. 2018;35(2):135-144.

116. McInnes IB, Mease PJ, Kivitz AJ, Nash P, Rahman P, Rech J, et al. (2020). Long-term efficacy and safety of secukinumab in patients with psoriatic arthritis: 5-year (end-of-study) results from the phase 3 FUTURE 2 study. The Lancet Rheumatology, 2(4), e227-e235. doi:10.1016/s26659913(20)30036-9.

117. Deodhar A, Mease PJ, McInnes IB, Baraliakos X, Reich K, Blauvelt A, et al. Long-term safety of secukinumab in patients with moderate-to-severe plaque psoriasis, psoriatic arthritis, and ankylosing spondylitis: integrated pooled clinical trial and post-marketing surveillance data. Arthritis Res Ther. 2019;21(1):111.

118. European Medicines Agency [Internet]. [cited 2021 Mar 31]. Available from: https://www.ema.europa.eu/en/medicines/human/EPAR/taltz\#authorisation-details-section.

119. Liu L, Lu J, Allan BW, Tang Y, Tetreault J, Chow CK, et al. Generation and characterization of ixekizumab, a humanized monoclonal antibody that neutralizes interleukin-17A. J Inflamm Res. 2016;9:39-50.

120. Brembilla NC, Senra L, Boehncke WH. The IL-17 Family of Cytokines in Psoriasis: IL-17A and Beyond. Front Immunol. 2018;9:1682. 
121. Martin DA, Towne JE, Kricorian G, Klekotka P, Gudjonsson JE, Krueger JG, et al. The emerging role of IL-17 in the pathogenesis of psoriasis: preclinical and clinical findings. J Invest Dermatol. 2013;133(1):17-26.

122. Megna M, Cinelli E, Balato A, Gallo L, Fabbrocini G. Efficacy and safety of ixekizumab in a group of 16 elderly patients with psoriasis over a 1-year period. J Eur Acad Dermatol Venereol. 2020;34(3):e152-e153.

123. Foulkes AC, Warren RB. Brodalumab in psoriasis: evidence to date and clinical potential. Drugs Context. 2019;8:212570.

124. European Medicines Agency [Internet]. [cited 2021 Mar 31]. Available from: https://www.ema.europa.eu/en/medicines/human/EPAR/kyntheum\#authorisation-details-section.

125. P3 Study Brodalumab in Treatment of Moderate to Severe Plaque Psoriasis (AMAGINE-2) [Internet]. [cited $2021 \mathrm{Mar} 31$ ]. Available from: https:/clinicaltrials.gov/ct2/show/NCT01708603?term=brodalumab\%2C+AMAGINE-2\&draw=2.

126. Efficacy and Safety of Brodalumab Compared With Placebo and Ustekinumab in Moderate to Severe Plaque Psoriasis Subjects (AMAGINE-3) [Internet]. [cited 2021 Mar 31]. Available from: https://clinicaltrials.gov/ct2/show/NCT01708629?term=brodalumab\%2C+AMAGINE$3 \&$ draw $=2 \&$ rank $=1$.

127. Lebwohl M, Menter A, Yamauchi P, Wu JJ, Lin T. Brodalumab in patients with psoriasis ages $<65$ and 65 years: 120-week findings from two phase 3 studies. J Am Acad Dermatol. 2019;81:4:AB176.

128. Bakirtzi K, Sotiriou E, Papadimitriou I, Sideris N, Vakirlis E, Lallas A, et al. Elderly patients with psoriasis: long-term efficacy and safety of modern treatments. J Dermatolog Treat. 2020:1-4. doi: 10.1080/09546634.2020.1809623. Epub ahead of print. PMID: 32783678.

129. Crowley JJ, Warren RB, Cather JC. Safety of selective IL-23p19 inhibitors for the treatment of psoriasis. J Eur Acad Dermatol Venereol. 2019;33(9):1676-1684. 


\title{
Bezbednost $i$ efikasnost inhibitora interleukina $u$ terapiji reumatoidnog artritisa, psorijaze $i$ psorijaznog artritisa u populaciji starih osoba
}

\author{
Jasmina Đuretic ${ }^{1 *}$ i Biljana Bufan ${ }^{2}$ \\ ${ }^{1}$ Univerzitet u Beogradu - Farmaceutski fakultet, Katedra za patobiologiju, \\ Vojvode Stepe 450, 11221 Beograd, Srbija \\ ${ }^{2}$ Univerzitet u Beogradu - Farmaceutski fakultet, Katedra za mikrobiologiju i \\ imunologiju, Vojvode Stepe 450, 11221 Beograd, Srbija \\ *Autor za korespondenciju, Jasmina Đuretić, e-mail: jasmina@pharmacy.bg.ac.rs
}

\begin{abstract}
Kratak sadržaj
Stariji pacijenti koji boluju od reumatoidnog artritisa, psorijaze ili psorijaznog artritisa uključuju one kod kojih je bolest imala kasni početak, nakon 60. godine starosti, ali takođe i one pacijente kod kojih je bolest počela ranije, a koji su ušli u staro doba. Imajući u vidu starenjem uslovljene promene imunskog sistema, moguću slabost starijih, podložnost infekcijama, prateći komorbiditet, koji uključuje i uzimanje više lekova, terapija ovih bolesti kod starijih pacijenata može predstavljati izazov. Inhibitori interleukina su se pokazali kao efikasna i bezbedna terapija ovih poremećaja. Međutim, stariji pacijenti sa ovim bolestima su često bili nedovoljno zastupljeni u ključnim kliničkim ispitivanjima inhibitora interleukina da bi se moglo sa sigurnošću utvrditi da postoji razlika u terapijskom odgovoru kod ovih pacijenata u odnosu na isti kod mlađih pacijenata. Cilj ovog rada bio je da prikaže nalaze od značaja za bezbednost i efikasnost terapije inhibitorima interleukina kod starijih pacijenata sa reumatoidnim artritisom, psorijazom ili psorijaznim artritisom. Nalazi ukazuju da je efikasnost inhibitora interleukina, prikazanih u ovom radu, uporediva kod starijih i mlađih pacijenata. Osim toga, incidencija neželjenih događaja se nije razlikovala između ove dve starosne grupe. Veća incidencija teških neželjenih događaja kod starijih pacijenata $u$ odnosu na mlađe bila je zabeležena $u$ terapiji reumatoidnog artritisa sarilumabom i psorijaze secukinumabom. Terapija reumatoidnog artritisa, psorijaze i psorijaznog artritisa inhibitorima interleukina može se smatrati efikasnom i bezbednom u populaciji starih pacijenata.
\end{abstract}

Ključne reči: inhibitori interleukina, stari pacijenti, bezbednost, efikasnost 